\title{
Correlation of raised serum uric acid in first trimester of pregnancy and the risk of gestational diabetes: a prospective study
}

\author{
Jayanthi Mohan, Janani Suriyamoorthi*, Maya Menon
}

Department of Obstetrics and Gynecology, ESIC Medical College and PGIMSR, KK Nagar, Chennai, Tamil Nadu, India

Received: 15 June 2017

Accepted: 08 July 2017

*Correspondence:

Dr. Janani Suriyamoorthi,

E-mail: jananisuriyamoorthi@gmail.com

Copyright: (C) the author(s), publisher and licensee Medip Academy. This is an open-access article distributed under the terms of the Creative Commons Attribution Non-Commercial License, which permits unrestricted non-commercial use, distribution, and reproduction in any medium, provided the original work is properly cited.

\begin{abstract}
Background: Prevalence of Gestational Diabetes Mellitus (GDM) is fast increasing in India. The association between serum uric acid levels and GDM is not well known. This study was conducted to assess the relationship between first trimester serum uric acid levels and the incidence of gestational diabetes.

Methods: This prospective observational study included 85 antenatal women. Serum uric acid level and oral glucose challenge test (OGCT) were done in all three trimesters. Women with first trimester serum uric acid levels of $<3.6 \mathrm{mg}$ were classified as group A and $>3.6 \mathrm{mg}$ as group B. Both the groups were followed throughout the pregnancy to assess the development of gestational diabetes. Also, the mode of delivery, pregnancy outcome, and other maternal and neonatal complications were observed.

Results: In the patients recruited into this study, $33.33 \%$ of group A (serum uric acid<3.6 mg/dl) and $17.5 \%$ of group B (serum uric acid>3.6 mg/dl) developed GDM.

Conclusions: First trimester Serum Uric acid was not significantly related to development of GDM in the sampled women. Neither was it related to any adverse maternal or fetal outcomes.
\end{abstract}

Keywords: First trimester, Gestational diabetes, Serum uric acid

\section{INTRODUCTION}

Gestational Diabetes Mellitus (GDM) is defined as carbohydrate intolerance with onset or first recognition during pregnancy. GDM is a rising problem in India. Several risk factors including obesity, physical inactivity and family history of diabetes, have been reported to be associated with GDM.

Primary objective of the study was assessing the first trimester uric acid levels and the development of GDM in the sampled women.

The secondary objective was to also observe the need for insulin, the mode of delivery, and the development of maternal and neonatal complications.
Uric acid is an important metabolite of purine metabolism in the body. Serial changes in serum uric acid concentrations have been studied in the preconception period and have been found to be associated with insulin resistance. Moreover, hyperuricemia is associated with the markers of metabolic syndrome like obesity and dyslipidaemia. It is possible that the association of uric acid with insulin resistance is causal. Several mechanisms have been proposed in the literature by which uric acid can cause insulin resistance.

\section{METHODS}

A prospective observational study was conducted among 85 pregnant women attending the antenatal OPD in a 
tertiary care medical college and teaching hospital in Chennai during a period of 18 months.

\section{Inclusion criteria}

- Singleton intrauterine pregnancy

- Regular antenatal visits

- No associated co-morbidity

- Not on any medications.

\section{Exclusion criteria}

- Multiple pregnancy

- Anaemia complicating pregnancy

- Chronic hypertension

- Gestational hypertension in present pregnancy

- Pregestational diabetes mellitus

- Thyroid disorders complicating pregnancy

- Renal and liver disease

- Obesity

- Other medical disorders complicating pregnancy.

During the first antenatal visit, a detailed history, general and obstetric examination were performed. Body Mass Index (BMI) was calculated. Antenatal investigations including Thyroid function test and Renal Function Test were done.

At the booking visit OGCT (measured by glucoseperoxidase method) and serum uric acid (measured by colorimetric assay) were measured. Women with OGCT $>140 \mathrm{mg} / \mathrm{dl}$ were considered as GDM and treated as per protocol. Serum Uric acid levels of $3.6 \mathrm{mg} / \mathrm{dl}$ was taken as the cut off. Patients with serum uric acid $<3.6 \mathrm{mg} / \mathrm{dl}$ were classified as group A and $>3.6 \mathrm{mg} / \mathrm{dl}$ as group B. Serum uric acid and OGCT were repeated at 24-28 weeks and during the third trimester.

\section{Oral glucose challenge test (OGCT)}

All antenatal mothers were given 75 grams of glucose mixed with $200 \mathrm{ml}$ of water and plasma glucose was measured after 2 hours. GDM was diagnosed when the plasma glucose was $\geq 140 \mathrm{mg} / \mathrm{dl}$ and they were subjected to oral glucose tolerance test (OGTT) and treated as per protocol.

\section{Statistical analysis}

The sample size was calculated for estimating a $10 \%$ difference in prevalence of GDM in relationship with serum Uric Acid levels for a 95\% confidence level and $80 \%$ power. The sample size was 85 pregnant women. All statistical analysis was performed by SPSS software version 22.0

Primary outcome of the study was observing the development of GDM in both groups. The secondary outcome was to assess the need for insulin, the mode of delivery, and the development of maternal and neonatal complications in both the groups.

\section{RESULTS}

A total of 85 women were enrolled in the study. Out of these women 45 belonged to low Uric Acid levels (group A) and the remaining 40 had high Uric Acid levels (group B). The incidence of GDM among the 85 women was 22 $(25 \%)$.

\section{Results of primary outcome}

Table 1: Incidence of GDM in pregnant women with low and high uric acid levels.

\begin{tabular}{|lllll|}
\hline Parameter & $\begin{array}{l}\text { Group A } \\
\text { low uric } \\
\text { acid levels }\end{array}$ & $\%$ & $\begin{array}{l}\text { Group B } \\
\text { high uric } \\
\text { acid levels }\end{array}$ & $\%$ \\
\hline GDM & 15 & 33.33 & 7 & 17.5 \\
\hline No GDM & 30 & 66.66 & 33 & 82.5 \\
\hline
\end{tabular}

In our study of total 85 patients 22 developed GDM. Of these $15(33.33 \%)$ belonged to group A with low Uric Acid levels, and 7 (17.5\%) belonged to group B with high uric acid levels with Chi square-2.77 ( $\mathrm{p}$ value 0.10) which is not significant. Our results showed that elevation of uric acid in diabetic patients was not statistically significant.

\section{Results of secondary outcome}

Table 2: Comparison of body mass index in group A and $B$.

\begin{tabular}{|lllll|}
\hline BMI & $\begin{array}{l}\text { Group A } \\
n=45\end{array}$ & $\%$ & $\begin{array}{l}\text { Group B } \\
n=40\end{array}$ & $\%$ \\
\hline$<18.5$ & 11 & 26.66 & 0 & \\
\hline $18.5-24.9$ & 23 & 53.33 & 28 & 71.42 \\
\hline $25-29.9$ & 6 & 13.33 & 12 & 28.57 \\
\hline$>30$ & 5 & 6.66 & 0 & \\
\hline Total & 45 & 100 & 40 & 100 \\
\hline
\end{tabular}

Table 2 compares the BMI between the two groups showing no significant difference.

Table 3: Insulin users in both groups amongst the 22 GDM patients.

\begin{tabular}{|lllll|}
\hline Parameter & Group A & $\%$ & Group B & $\%$ \\
& GDM $n=15$ & GDM $n=7$ & $\%$ \\
\hline Insulin & 3 & 50 & 3 & 50 \\
\hline
\end{tabular}

Table 3 Amongst the 22 GDM patients 6 needed insulin. The distribution of insulin users was equal in group $\mathrm{A}$ and $\mathrm{B}$ and hence statistically insignificant.

Table 4 compares the mode of deliveries between the groups which was also not statistically significant. 
Table 4: Mode of delivery in the two groups.

\begin{tabular}{|llll|}
\hline Group A & & Group B & \\
\hline $\begin{array}{l}\text { Normal } \\
\text { delivery }\end{array}$ & $26(57 \%)$ & $\begin{array}{l}\text { Normal } \\
\text { delivery }\end{array}$ & $22(55 \%)$ \\
\hline Cesarean & $19(42 \%)$ & cesarean & $18(45 \%)$ \\
\hline
\end{tabular}

Table 5 shows statistically insignificant maternal complications between the two groups. The distribution of neonatal complications was also similar in both groups.

Table 5: Maternal complications in both groups.

\begin{tabular}{|lllll|}
\hline Parameter & $\begin{array}{l}\text { Group } \\
\text { (n=45) }\end{array}$ & $\%$ & $\begin{array}{l}\text { Group B } \\
(\mathrm{n}=40)\end{array}$ & $\%$ \\
\hline $\begin{array}{l}\text { With } \\
\text { complication }\end{array}$ & 4 & 8.88 & 3 & 7.5 \\
\hline $\begin{array}{l}\text { Without } \\
\text { complications }\end{array}$ & 41 & 91.11 & 37 & 92.5 \\
\hline
\end{tabular}

\section{DISCUSSION}

In present study, out of 40 women in group B (serum uric acid $>3.6 \mathrm{mg} / \mathrm{dl}$ ), only 7 developed GDM which constitutes $17.5 \%$, and out of 45 women in group $\mathrm{A}$ (serum uric acid $<3.6 \mathrm{mg} / \mathrm{dl}$ ) 15 developed GDM which constitutes $33.33 \%$ with $\mathrm{p}$ value of 0.10 . Our study supports null hypothesis as there is no significant correlation between raised first trimester serum uric acid and development of GDM.

Our findings are consistent with a study conducted by Pundalik B et al conducted a prospective study in Mangalore, India from January 2011 to September $2012 .{ }^{1}$ Study included 178 women before 20 weeks of gestation for whom the serum uric acid and OGCT was measured. OGTT between 24-28 weeks were measured for patients with positive OGCT and were followed up for the development of GDM. Their findings did not support assessing first trimester serum uric acid concentration in pregnant women to predict the development of GDM as area under the ROC curve was 0.7 for first trimester uric acid levels.

Güngör ES et al in which 112 patients were recruited in Turkey and serum uric acid, creatinine, albumin and liver enzymes were measured on booking visit and between 24-28 weeks of which 56 had gestational diabetes and they were followed throughout. ${ }^{2}$ Their results showed that elevation of uric acid in diabetic patients was not statistically significant $(4.42+/-1.09$ vs. $4.1+/-0.84 \mathrm{mg} /$ dl), $\mathrm{p}>0.05$.

Javadian $\mathrm{P}$ et al in Iran during April 2007 to August 2010. 52 GDM women (according to ADA criteria) were taken as cases and 50 non-diabetic women matched to the duration of pregnancy were taken as controls. ${ }^{3}$ Serum ferritin, uric acid, malondialdehyde, triglycerides were measured at 24-28 weeks of gestation for both the groups. Their results showed that the difference in serum uric acid was not statistically different between the two groups (Uric Acid 5.12 \pm 1.9 versus 5.61 \pm 1.38 5), p value0.145 .

Singh R et al on 100 antenatal GDM cases in Ajmer, India evaluated serum levels of homocysteine, vitamin B12, folic acid, fasting glucose and fasting insulin were measured and compared with 100 non- GDM control subjects and concluded that the difference in uric acid between the two study groups $(4.68 \pm 1.00 \quad 4.86 \pm 1.11)$ $\mathrm{P}>0.2158$ was not statistically significant. ${ }^{4}$

The following studies had a similar cut off for uric acid levels in their study

Table 6: Comparing the results of previous studies.

\begin{tabular}{|c|c|c|c|c|c|}
\hline Study & $\begin{array}{l}\text { Uric acid cut- } \\
\text { off }(\mathrm{mg} / \mathrm{dl})\end{array}$ & Sample size & Country & Year & Result \\
\hline Laughon SK et $\mathrm{al}^{5}$ & 3.6 & 1541 & USA & $1997-2002$ & 3.25-fold increased risk \\
\hline 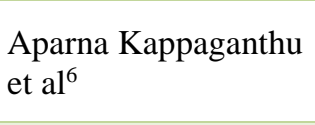 & 3.4 & 225 & India & 2013 & $\begin{array}{l}\text { Sensitivity- } 90 \% \\
\text { Specificity-95\% } \\
\text { NPV-99\% in predicting GDM }\end{array}$ \\
\hline Rajakumar SA et al $^{7}$ & 3.6 & 1002 & India & 2006 & $\begin{array}{l}\text { +ve correlation } \\
\text { p value- } 0.003\end{array}$ \\
\hline Zhou $\mathrm{J}$ et $\mathrm{al}^{8}$ & $1.44-3.83$ & 1000 & China & 2012 & $\begin{array}{l}\text { 2.34-fold increased risk of } \\
\text { GDM }\end{array}$ \\
\hline Present study & 3.6 & 85 & India & 2015 & No correlation with GDM \\
\hline
\end{tabular}

But these studies showed significant correlation between serum uric acid levels and the development of GDM.
However, our study did not show any correlation between first trimester serum uric acid and development of GDM. 
Probably further multicentre studies with larger sample size may enlighten the correlation between serum uric acid and Gestational diabetes mellitus.

\section{ACKNOWLEDGMENTS}

Authors would like to thank Dr. Sridevi TA, Dr. Vijayaprasad Gopichandran, Dr. Mohanavalli Singaram, Dr. R. Anuradha for support during study.

\section{Funding: No funding sources}

Conflict of interest: None declared

Ethical approval: The study was approved by the Institutional Ethics Committee No 9/27/10/2014

\section{REFERENCES}

1. Baliga $P$, Thunga S. Uric acid levels in early pregnancy as a predictor of preeclampsia and gestational diabetes mellitus. Internat J Recent Scient Res. 2015;6(6):4611-5.

2. Güngör ES, Danisman N, Mollamahmutoglu L, Relationship between serum uric acid, creatinine, albumin and gestational diabetes mellitus. Clin Chem Lab Med. 2006;44:974-77.

3. Javadian P, Alimohamadi S, Gharedaghi $\mathrm{MH}$, Hantoushzadeh S. Gestational diabetes mellitus and iron supplement; effects on pregnancy outcome. Acta Medica Iranica. 2014;52(5):385.
4. Singh YR, Soni N, Kaushik GG, Sharma S, Broca JS. Study of serum levels of Homocysteine, Vitamin B12 and Folic acid in women with aprevious history of Gestational Diabetes Mellitus. SSRG Int J Med Sci (SSRG-IJMS). 2016;3(3).

5. Laughon SK, Catov J, Provins T, Roberts JM, Gandley RE. Elevated first-trimester uric acid concentrations are associated with the development of gestational diabetes. Am J Obstet Gynecol. 2009;201(4):402:e1-5.

6. Kappaganthu A, Sachan J, Shailaja G. Hyperuricemia in early pregnancy a marker for gestational diabetes mellitus. IOSR J Dental Med Sci. 2014;12:51-54.

7. Rajakumar SA, Thirumal R, Usha V, Rontgen R. CoRelation between First Trimester Uric Acid Concentration and Development of Gestational Diabetes Mellitus. J Evol Med Dental Sci. 2014;3(02):266-271.

8. Zhou J, Zhao X, Wang Z, Hu Y. Combination of lipids and uric acid in mid-second trimester can be used to predict adverse pregnancy outcomes. The J Maternal-Fetal Neonat Medic. 2012;25(12):2633-8.

Cite this article as: Mohan J, Suriyamoorthi J, Menon M. Correlation of raised serum uric acid in first trimester of pregnancy and the risk of gestational diabetes: a prospective study. Int J Reprod Contracept Obstet Gynecol 2017;6:3633-6. 